\title{
Photovoltaics and zero energy buildings: a new opportunity and challenge for design
}

\author{
Alessandra Scognamiglio ${ }^{1 *}$ and Harald N. Røstvik ${ }^{2}$ \\ ${ }^{1}$ ENEA (Italian National Agency for New Technologies, Energy and Sustainable Economic Development)—Photovoltaic Technologies \\ Area, Portici Research Centre, Portici (NA), Italy \\ 2 Sivilarkitekt MNAL Harald N. Røstvik AS, Stavanger/Bergen School of Architecture, Bergen, Norway
}

\section{ABSTRACT}

Starting from the end of 2020, all new buildings will have to be Nearly Zero Energy Buildings (Nearly ZEBs-ED 2010/31/EU recast). This new 'energy paradigm' might be a revolution for architecture and for Photovoltaics (PV) too, but there are both cultural and technical obstacles to overcome. There is a need to re-think the way buildings are designed (integrating renewables for being ZE). There is a need to re-think the way PV is designed in buildings. PV will be gaining an increasing relevance in the ZEBs design, thanks to its features and potentialities (suitability for any kind of energy demand of the building, easiness of building integration, cost). In a ZEB scenario, PV is very suitable for generating energy, 'on site' and 'at site'; this enlarges the perspective of use of PV from the architectural scale to a wider scale, including the space close to the building or even to the urban and landscape scale. In such a new context, the existing research on the relationships between PV and architecture, focusing mainly on the way the PV components are used in relation to the envelope (Building-integrated PV/Building-added (Attached) PV), is no longer sufficient. The authors envision possible formal results, opportunities and challenges, for the use of PV in ZEBs, as well as new research issues for the future relationships between PV and ZEBs from the architecture and landscape design point of view. Copyright (c) 2012 John Wiley \& Sons, Ltd.

\section{KEYWORDS}

Building-integrated Photovoltaics (BIPV); Photovoltaics design; Net Zero Energy Buildings; PV use in Net Zero Energy Buildings; Landscape-integrated Photovoltaics (LIPV)

* Correspondence

Alessandra Scognamiglio, ENEA (Italian National Agency for New Technologies, Energy and Sustainable Economic Development)— Photovoltaic Technologies Area, Portici Research Centre, Portici (NA), Italy.

E-mail: alessandra.scognamiglio@enea.it

\section{INTRODUCTION}

The recast of the European Directive 2010/31/EU establishes that starting from the end of 2020, all new buildings will have to be Nearly Zero Energy Buildings (Nearly ZEBs).

According to this directive, 'Nearly ZEB' means a building that has a very low energy yearly energy consumption, which can be achieved by both the highest energy efficiency and by energy from renewable sources, which shall be 'on-site' or 'nearby' [1].

A relevant international effort on the subject of the Net Net ZEBs-Net ZEB meaning that the buildings are connected to an energy infrastructure-is ongoing in the International Energy Agency (IEA), joint Solar Heating and Cooling (SHC) Task 40 and Energy Conservation in Buildings and Community Systems Annex 52, titled 'Towards Net Zero Energy Solar Buildings' [2,3].
Both from the theoretical and practical points of view, this new 'energy paradigm' - or the Net ZEB) balancemight be a revolution for architecture and for Photovoltaics (PV), too.

The engineering only research taking into account mainly the energy aspects seems to be not sufficient to ensure the diffusion of ZEB models: in achieving the ZEB target, a major role will be played by architects and designers, who are amongst the main actors of this revolutionary change. More precisely, because the form of our buildings and cities might change radically because of this new energy requirement, the way architects will take up the challenge of designing ZEBs is crucial, as architects are highly responsible of the form of the city and of its symbolic meanings [4-7].

In a near future, buildings will be designed to need very little energy (passive design strategies for energy efficiency) and to integrate active surfaces (i.e. PV modules) for generating energy. This approach requires a new thinking, able to 
use the energy we need as an input for design. The energy we use should be seen as a variable able to relate itself to the form of our buildings (or clusters of buildings or even cities and landscapes), instead of being seen as a kind of abstract variable that design cannot deal with. In the future, design has to consider not only the space we use directly but also the space required to provide for electrical and thermal energies from renewable sources: the surface necessary for placing the energy generation devices. This area can be defined as the 'building's energy footprint' [8]. Because the renewable energy generation systems, in contrast to conventional energy sources, are visible, for the first time in the tradition of architecture, energy can take a 'form' (i.e. shape, colours and features of a PV generator), and architects are responsible for designing this form(s).

Photovoltaics has many potentialities in a ZEB scenario, thanks to its features and enormous decrease in cost.

Because of the high energy consumption of the European countries, PV can contribute significantly to the reduction of the primary, conventional energy supply, as well as to the reduction of the $\mathrm{CO}_{2}$ emissions [9]. PV seems to be technically the easiest way to obtain the zero energy balance, as the recent, sharp, drop in prices makes it competitive even with active solar thermal collectors and building materials in general.

Photovoltaics is able to generate electric energy from the direct conversion of the sunlight; it can power any kind of energy request of the building (thermal and electrical), with the consequence that a ZEB could be theoretically entirely powered by PV.

Photovoltaics can be used exactly where the energy is consumed ('on-site' energy generation). It can be easily integrated anywhere into the building envelope, allowing for a number of functions: that is, on/in rooftops, opaque and semitransparent envelope surfaces, having a structural function as well as sun-shading and cladding function and so forth (Figure 1), and enabling also a construction costs reduction $[10,11]$

This condition advantages PV over other renewable sources because only few of them are suited for being used very close to the building and only even fewer can be integrated into the building envelope (PV and solar thermal). PV can be used also in combination with such technologies, allowing for an optimal energy design of the building.

Furthermore, thanks to the dramatic decrease in costs, today PV can be considered a 'standard' material for buildings with the advantage of generating energy: a PV module costs in the order of $100 \mathrm{EUR} / \mathrm{m}^{2}$ [12] and generates about $80 / 150 \mathrm{kWh} / \mathrm{m}^{2} /$ year at an efficiency of $120 \mathrm{~W} / \mathrm{m}^{2}$.

These considerations on the potentialities of PV in achieving the ZE balance suggest a very simple architectural implication: $\mathrm{PV}$ is going to become an indispensable material for buildings, with the consequence of being in a near future a very visible part of the building composition [13].

Because of the mandatory request for buildings to achieve the Net ZE balance, if today PV plays a minor role in the composition of the most of our buildings

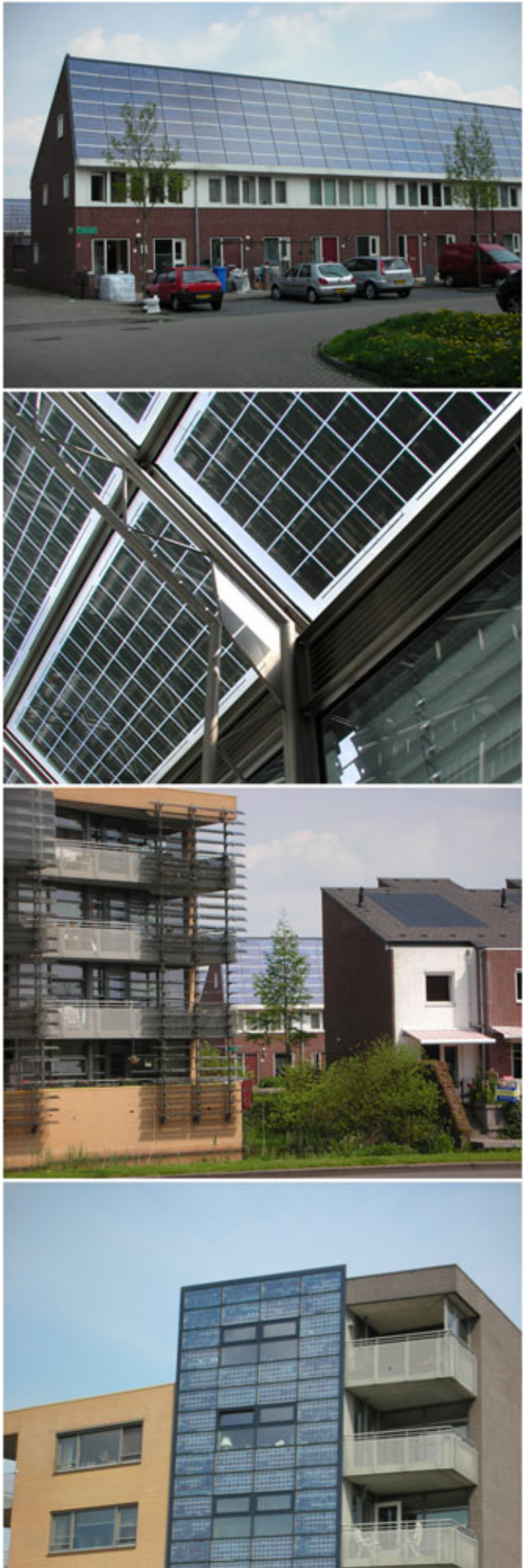

Figure 1. Examples of different ways of integrating PV in (or adding $\mathrm{PV}$ to) the building envelope (rooftops, semitransparent envelopes, sun-shading and cladding). Pictures (CA. Scognamiglio. 
envelopes - small surfaces - in a near future, it will have a main role, as PV surfaces in buildings will likely become bigger and bigger.

The consequent influence of the use of PV on the architectural image of the building, and on the way the city itself can look like, is very considerable, opening up a new wide perspective for the relationship between PV and architecture.

For many reasons, which we will clarify later in the paper, if we look at the use of PV in ZEBs, the existing research on the use of PV in buildings could be not sufficient.

Until now, in fact, much research has been carried out on how to use PV in buildings focusing on technical, aesthetical (and economical) aspects. Nevertheless, the relationship between PV and the energy balance of the building was not the main concern.

The need to meet the ZEB balance opens new perspectives for the use of PV: PV might, in fact, be used into the building envelope ('Building-integrated PV (BIPV) or Building-added/attached PV (BAPV)), and also, it might be used close to the building ('on-site' or 'nearby' energy generation) accounting for the building energy balance. Furthermore, the boundary of the building's balance could be also extended to a cluster of buildings, with the consequence that the use of PV should be described and accounted not for a single building but for a cluster of buildings.

In this condition, it seems unpostponable to open a design investigation on the use of PV in Net ZEBs, where ZEB balance is the main target of design.

The main questions that the authors of this paper would like to bring forward are as follows: taking into account a hypothetical ZEB scenario, are there new research issues for PV? Are there new possible perspectives for investigating the relationship between PV and its use in our buildings, cities and landscapes? If there are some new issues and relationships to be taken into account, are there any consequences on the product market development for PV?

These questions should be approached both from the engineering and from the architectural point of view, trying to create a bridge over scientific knowledge and architecture's practice. The authors of this paper aim to give a contribution to the investigation of the architectural aspects by envisioning some possible new research issues that overlap the two disciplinary domains and opens towards an interdisciplinary approach.

\section{THE USE OF PV IN ZERO ENERGY BUILDINGS: CHALLENGES AND POTENTIALITIES FROM AN ARCHITECTURAL PERSPECTIVE}

If we look at the history of the use of PV in architecture, we can observe that in the case of the early pioneering buildings, PV was a new device for architects. Later, thanks to research in aesthetics and technology, PV evolved from a functional element stuck on top of buildings (in the hope that it would be visually eliminated by the good intentions of ecologists who pretend not to see it) to an innovative building material accepted from the aesthetical point of view and relatively easy to use.

Today PV, if conceived together with the building from the beginning of the design process, can be understood as a smart and adaptive technology to transform ordinary buildings into 'trendy' and contemporary energy generators, also because of its social and symbolic meaning [14].

What is the likely evolution of the use of PV for buildings when looking at a ZEBs scenario?

The change in perspective form buildings that consume energy to ZEBs - which generate the energy they consume from PV-will have a crucial impact on the formal image of the building — as well as on the building's energy balance. It cannot but being exploited as 'design' by architects: a small PV system can be easily hidden or integrated somewhere in the building, but a large one requires much more design attention.

From this point of view, the design potential of PV could turn a legal constraint into a new challenging opportunity for architects; however, cultural and technical obstacles need to be overcome.

From a cultural point of view, despite it is theoretically highly recognized by architects that buildings should be conceived as power plants and habitats [15]; in reality, PV (and the use of renewables in general) is still not perceived as a creative challenge by architects but rather as necessity that cannot be postponed, and it is mostly imposed by legislators. A vague sense of guilt and the difficulty in disengaging from the era of oil appear to be the reasons for this hesitance. Buildings have to comply with regulations and consequently employ such technology as PV, but systems that use fossil-based fuels, however, seem to be less expensive, at least when it comes to their components and investment costs, and they enjoy greater 'credibility' merely because architects, contractors and craftsmen are more familiar with them [16].

From the technical point of view, the main obstacles to face are intrinsic in the ZEB target compared with the features of the PV technology.

There is a limit to how much energy can be generated per square meter PV collector (depending basically on the PV efficiency, on the tilt and azimuth angles of the PV generator and on the latitude, as well as on the BOS efficiency). As an example, in the case of optimal positioning of the PV system (tilt and azimuth angles), a typical generation in northern climates such as North Europe would be around $80-100 \mathrm{kWh} / \mathrm{m}^{2}$ collectors per year as usable energy. In southern climates such as South Europe, a typical generation would be around $130-180 \mathrm{kWh} / \mathrm{m}^{2}$ collectors per year as usable energy [17].

Because in the case of ZEBs the use of PV has to be related to the energy needs of the building (ZEB balance), in absence of other energy generation systems, PV yield should aim at balancing the energy request of the building.

Because of the low energy density of PV, the building envelope might not be sufficient to generate all the energy the buildings needs. 
These considerations lead to a possibility of using PV in proximity of the building when the envelope surfaces available for PV are not large enough for achieving the ZEB balance. Moreover, a ZEB, when connected to the grid (Net ZEB) might have a fully matched annual energy balance, but in the case of PV, the load match (the fraction of electricity directly consumed) is in the range of $30 \%$ or even less. For this reason, it could be favourable to feed electricity into a grid for nearby consumption in another building. As a consequence, the issue of PV in ZEBs should be discussed on the level of the building as well as on the level of the buildings cluster or at the urban scale.

This condition points also towards the architectural focal point of the discussion that this paper would like to open: the need of investigating the use of PV in ZEBs from the architectural scale (one building) to the urban scale (a cluster of buildings) or, even, to the landscape scale (a whole landscape).

\section{PV IN BUILDINGS: STATE OF ART AND PERSPECTIVES}

\subsection{PV in buildings: state of art}

The use of PV in buildings is under investigation since more than 20 years now, being recognized as a key factor for the exploitation of $\mathrm{PV}$ and the reduction of the $\mathrm{CO}_{2}$ emissions of buildings [18-22].

From an architectural point of view, the way PV is used in the building can be described according to different approaches.

One approach is describing PV looking at the building as a formal whole: PV plays a certain role in the envelope composition and in exploiting a certain architectural meaning of the building [23]
For instance, "attractiveness" is a guide concept used to describe 'urbanmarks', which are large architectural objects, almost sculptural in appearance, that attract the attention of the public. Because today's public is very interested in renewable sources of energy, an urbanmark can attract public attention by the use of PV because of its physical recognisability as a symbol of sustainability.

An example of such urbanmark is the PV Pergola, designed by the Spanish architects Torres \& Lapeña and built for the Forum 2004 in Barcelona.

The Pergola (Figure 2) is essentially a large PV plane (about $500 \mathrm{~kW}_{\mathrm{p}}$ ), supported by four concrete structures, which forms an inclined sloped roof. Here, the conspicuous use of PV, and also the shaded area under the roof of the Pergola that provides refuge from the hot, sunny Forum, attracts the public. By that time, because of its high iconic value, the PV Pergola has become the visual symbol of the Forum itself.

Nevertheless, the most common way of describing the use of PV in buildings categorizes the use possibilities according to a technological perspective, which focuses in particular on the way the PV modules are used in the envelope system. In this case, PV is mainly understood as PV components, which either substitute (BIPV) or overlap (BAPV) standard building elements [24,25].

According to this distinction between BIPV and BAPV, two main types of PV products can be used for buildings, BAPV products: they require additional mounting systems and BIPV products: they meet all the building envelope requirements (such as mechanical resistance and thermal insulation) and can substitute entirely envelope components. In some countries, this distinction is very important for accessing different feed in tariff incentives values (i.e. Italy) [26].

A variety of special PV components has been developed lately and is available on the market to match building integration needs $[27,28]$.

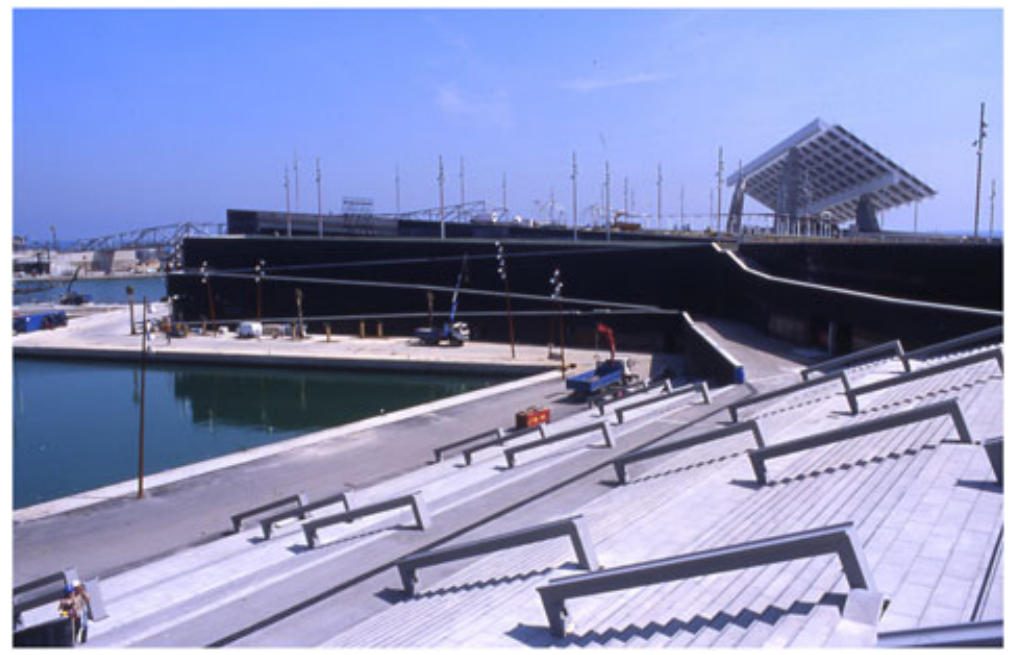

Figure 2. Forum 2004 Esplanade and Pergola, Barcelona, Spain, 2004. PV helps in defining the landmark function of the Pergola. Design Torres \& Lapeňa. Picture by courtesy of the architects @Torres \& Lapeña. 
The aesthetics of PV products and their integration into the building's skin have been studied intensively, and aesthetics has been identified and emphasized as a key factor for the success of the implementation of PV in the built environment [29-33].

The building envelope offers many design possibilities for integrating or adding/attaching PV modules (Figure 3). Basically, PV can be used in/on roofs, facades and external devices. Six main categories have been set up in the context of the IEA SHC Task 41 "Solar Energy and Architecture" (in press on the Task 41 website).

These categories are as follows: added technical element; added elements with double function; free standing structure; part of surface composition; complete façade / roof surface; form optimized for solar energy; other (if not in 1-6 categories).

In many buildings, from the 1990s up to now, PV has been used in a very successful way from the architectural point of view both in new ones and in pre-existing ones (retrofit).

As examples, we will give, respectively, two Italian cases: the Polins (Figure 4), designed by Marco Acerbis [34] and built in Portogruaro (Venice) in 2009 [35], and the Renovation of a 'tabià' into an energy self-sufficient building (Figure 5), designed by EXiT Architetti Associati [36] and built in 2012 in Selva di Cadore (Belluno) [37]. Both architects are Italian.
The Polins is a multifunctional building (offices, meeting rooms, auditorium). Facing south, form and materials were studied to maximize solar gains and minimize energy requirements in summer and winter.

Design-wise, the PV system $\left(5.7 \mathrm{~kW}_{\mathrm{p}}\right.$ on an area of about $40 \mathrm{~m}^{2}$ ) forms a natural continuation of the roof, which separates geometrically from a continuous sheet into rows of PV modules. These modules become a simple but refined part of the architecture: although nothing special in themselves, they form an essential part of the building's design, in particular because sitting along the main south-facing front, at the top of the laminate wood arches. They protect this outward extension of the building, preventing overheating inside in the summer months when the sun reaches its maximum elevation and irradiation, and favour solar capture in the winter months.

'Tabià' are named old buildings used as a stable or barn, which characterize the agricultural and pastoral architecture of the Selva di Cadore Valley in the landscape of the Italian Dolomites, classified as a UNESCO World Heritage site.

One of these buildings was renovated and transformed into an energy self-sufficient holiday home thanks to PV, which supplies heat, hot water, cooking systems and other electrical appliances.

The EXiT's project is successful thanks to the attention that the designers paid to replace the wood of the old roof with PV modules, coming up with a solution that is both
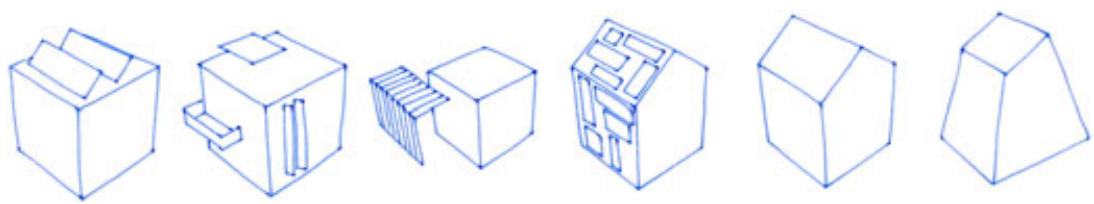

Figure 3. $P V$ and the technological integration into the envelope. Conceptual integration typologies of PV elaborated in IEA SHC-Task 41 (re-designed by the author). From left to right: added technical element; added elements with double function; free standing structure; part of surface composition; complete facade/roof surface; form optimized for solar energy; other (if not in 1-6 category). Image A. Scognamiglio.

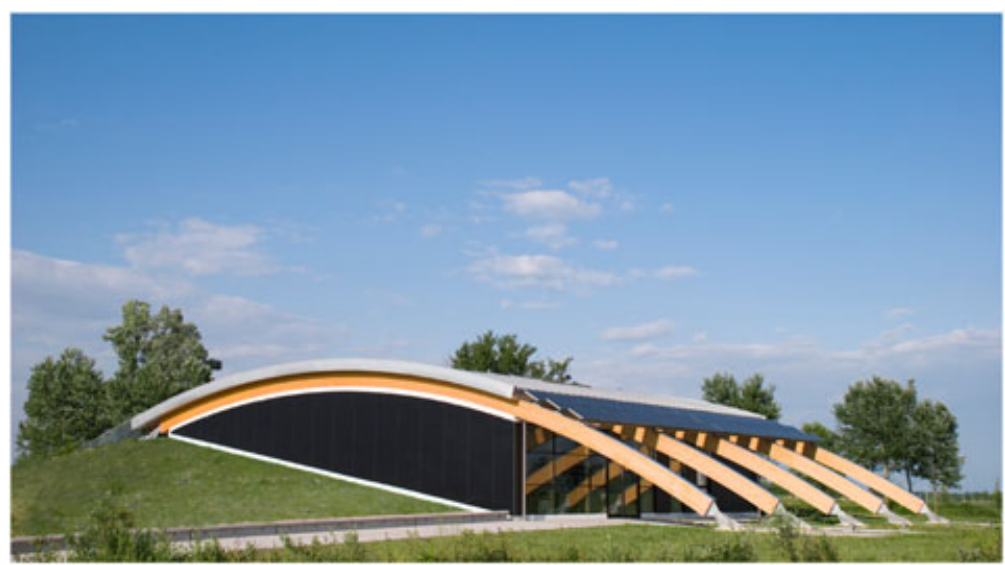

Figure 4. Polins, Portogruaro (new building), Italy, 2010. PV is part and parcel of the curved sun-shading system of the southern facade. Design: Marco Acerbis. Picture by courtesy of the architect @M. Acerbis. 


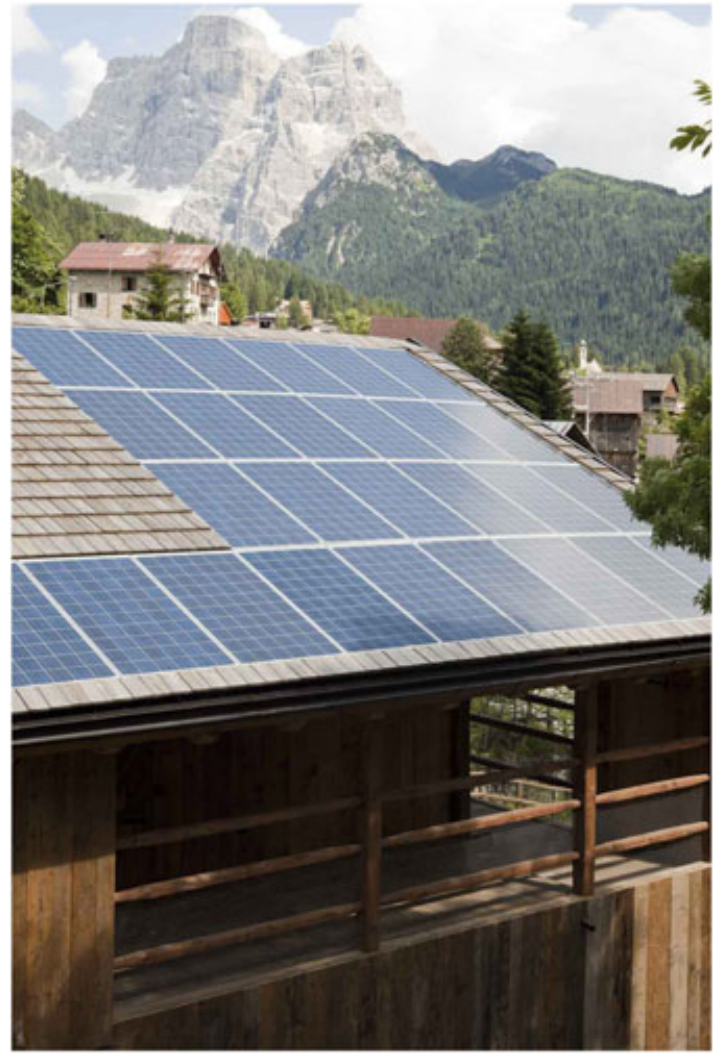

Figure 5. Energy self-sufficient tabià (retrofit), Selva di Cadore (Belluno), Italy, 2010. PV is part and parcel of the pre-existing wooden tilted roof. Design: EXiT. Picture by courtesy of the architects (CT. Cos.

attentive and respectful. A new and visible steel structure painted black works with the original wood to accommodate the opaque standard PV modules.

This system links the existing wooden shingles and the new $51 \mathrm{PV}$ modules. The whole system has a nominal power of nearly $12 \mathrm{~kW}_{\mathrm{p}}$, occupying overall about $84 \mathrm{~m}^{2}$. The yearly energy production is about $13 \mathrm{MWh}$, making the tabià completely energy self-sufficient and non-polluting.

\section{2. $P V$ in buildings: perspectives}

Unfortunately, in recent years, green-washing practices are established in the field of architecture. According to the Dutch architect Rem Koolhas, the ecological promise has even become the obligatory ornament of contemporary building practice [38].

With regard to PV, until now, it often happened that in some remarkable architectures-also good examples of BIPV_-few PV modules (often custom designed) were used, as kinds of 'jewels' mounted in the building envelope. This approach — not really energy responsible but legitimate in absence of specific regulatory requirement-was not properly taking into account the overall energy demand of the building but rather, the aesthetical and iconic result of the use of PV.

As an example, we will give the Opera in Oslo, Norway, designed by the Norwegian architects Snøhetta [39], built in 2008 and widely recognized as an architecture masterpiece (Figure 6).

The building is a landmark for the area of the Oslo Fjord, and it shows a very large glazed semitransparent PV façade that faces the sea and constitutes the appealing envelope of the restaurant area. The PV generator $\left(400 \mathrm{~m}^{2}, 24 \mathrm{~kW}_{\mathrm{p}}\right)$ is designed as a composition of glass-glass modules, having different sizes and shapes and characterized by a linear strip pattern of PV cells, which contributes to the general image of the facade, being at the same time decoration and shadow. From the architectural point of view, it can be considered very successful: a perfect case of BIPV achieving a good overall aesthetical performance with the use of appealing and multifunctional PV modules. Nevertheless, if we shift from the architecture point of view to the energy one, it only provides a very negligible percentage of the building energy demand [40].

The use of PV that the Opera shows does not imply directly a 'green-washing attitude' but rather, the attempt to use in an architectural way a technology (PV) that architects are still not familiar with. It is thanks to such attempts that the public today knows PV; nevertheless, this example gives us food for thinking.

We gave this example, in fact, because the Opera in Oslo is a clear case of the way solar energy and PV in particular is generally used according to the current architectural attitude, satisfying also the design quality desires of the BIPV experts.

When there is no specific (or mandatory) request of balancing the energy consumption and generation of the building, PV can be used as an icon for sustainability, but despite this use of PV can be trickily-because the impression given is that the building at hand is a solar powered building - this 'smart' use of PV does not imply that the building is a 'solar building', meaning a building primarily being powered by solar energy.

Such an example shows that in the absence of a mandatory requirement on the NZEB target-and consequently, without any special focus on the ZEB balance-often designers do not grasp the core content of the challenge of designing a solar powered building: that is actually making it energy efficient enough to put the solar at work in it as a considerable contribution.

This consideration leads towards one of the crucial questions of this work: what happens when PV has to be designed on the energy balance of the building? What happens when an energy calculation has to be transformed by design into an architectural form for a building?

\section{BASICS OF NET ZERO ENERGY BUILDING DESIGN}

A consistent definition framework has been proposed for defining a Net ZEB [41]. 

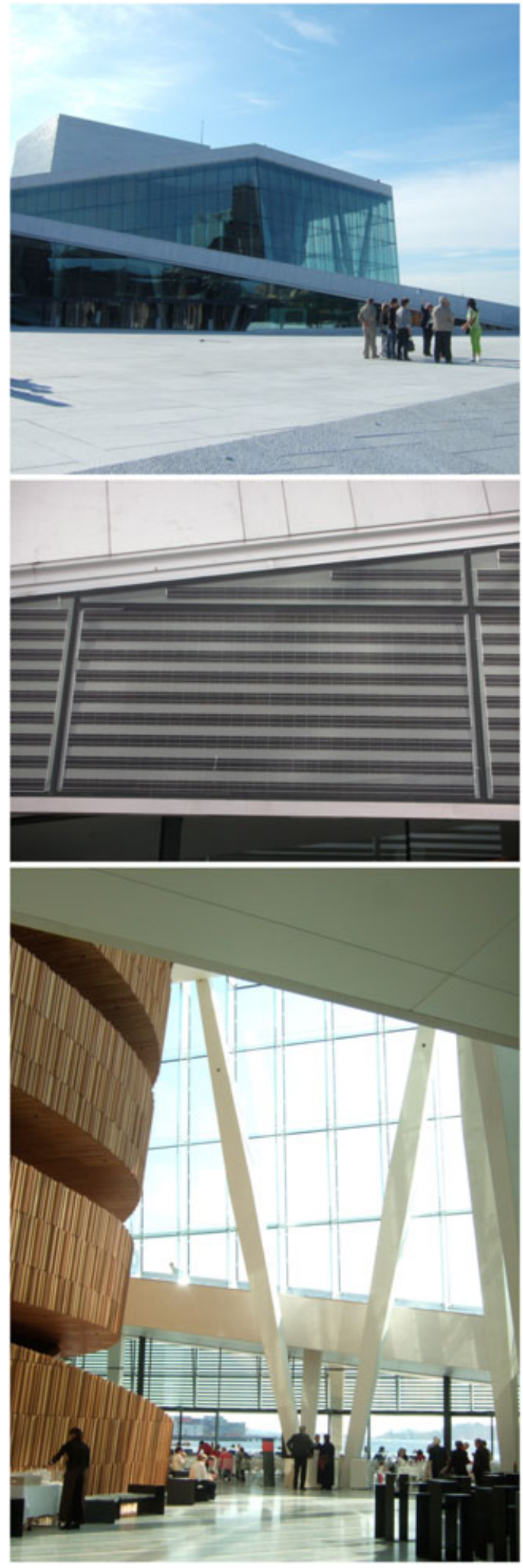

Figure 6. Opera House, Oslo, Norway, 2008. The long triangular band above people's head is the glass part where the $400 \mathrm{~m} 2$ solar $\mathrm{PV}$ is mounted in a pattern made of cells strips. Design: Snøhetta. Pictures $\odot$ H. N. Røstvik and A. Scognamiglio.
A ZEB is commonly understood as an energy-efficient building able to generate electricity, or other energy carriers, and form renewable sources to compensate for its energy demand. Therefore, it is implicit that there is a focus on buildings that are connected to an energy infrastructure and not on autonomous buildings (Net ZEBs).

Some methodology issues useful for the definition of a Net ZEB are very relevant also from the architectural design point of view. In the following, we will clarify some basics, and then, we will go through those issues crossing over the engineering and the architectural design.

Building system boundary. The boundary at which compare energy flows flowing in and out of the system.

It includes 'physical boundary' and 'balance boundary'. Physical boundary can encompass a single building or a group of buildings and determines whether renewable resources are 'on-site' or 'off-site'. Balance boundary determines which energy uses (e.g. heating, cooling, ventilation, lighting and appliances) are included in the balance.

Generation. Building's energy generation, specified per each energy carrier in $\left(\mathrm{kWh} /\right.$ year) or $\left(\mathrm{kWh} / \mathrm{m}^{2} /\right.$ year $)$.

Net ZEB balance. A condition that is satisfied when weighted supply (the sum of all exported energy or generation, obtained summing all energy carriers each multiplied by its respecting weighting factor) meets or exceeds weighted demand over a period, nominally a year ('import/ export balance' or 'load/generation balance').

The NZEB balance is calculated as follows.

$$
\begin{aligned}
\text { Net ZEB balance } & : \rightarrow \text { weighted supply } \rightarrow- \\
& \rightarrow \text { weighted demand } \rightarrow=0
\end{aligned}
$$

A list of priorities can be set to orient the design choices for ZEBs:

(1) Reduce the energy demand by means of energy efficiency measures.

(2) Generate electricity as well as thermal energy carriers by means of energy supply options to obtain enough credits to achieve the balance.

\section{NET ZERO ENERGY BUILDING BALANCE AND DESIGN BOUNDARIES}

For the investigation brought forward by this paper, it is very important to understand what are the design issues related to the 'building system boundary' and their possible relationships with the use of PV.

The physical boundary of the building's system can be on a single building or on a cluster of buildings. Such buildings included in a ZE cluster would perform as a whole: the $\mathrm{ZE}$ target is not achieved at the building scale (for each single building) but at the cluster scale. The cluster works as a system. 
The use of renewables in ZEBs has been described as five possible options: generation 'on building's footprint'; 'on-site' generation from 'on-site' renewables ('at-site' energy generation); 'on-site' generation from 'off-site' renewables; 'off-site' generation; 'off-site' supply [42,43].

The energy generation is considered 'on-site' if the energy generation system is within the boundary of the building, namely the building's footprint. The building's footprint is the physical boundary of the building itself: the building's footprint is the outline of the total area of a lot or site that is surrounded by the exterior walls of a building or portion of a building, exclusive of courtyards. In the absence of surrounding exterior walls, the building footprint shall be the area under the horizontal projection of the roof [44].
The 'at-site' energy generation implies that the energy generation system is detached from the building, and it is placed within the building 'site's' boundary.

Note in reality that the building's site boundaries are defined by property rights, and the possibility of using the site for placing energy generation systems is limited by the site features: solar access, morphology, etc.

For accounting the PV energy generation as 'on-site' (within the building's footprint + at building's site), the balance boundary can be set theoretically wherever one prefers, considering PV generators that are detached from the building but within the building's site boundary. Nevertheless, from the architectural point of view, the issue is complex.
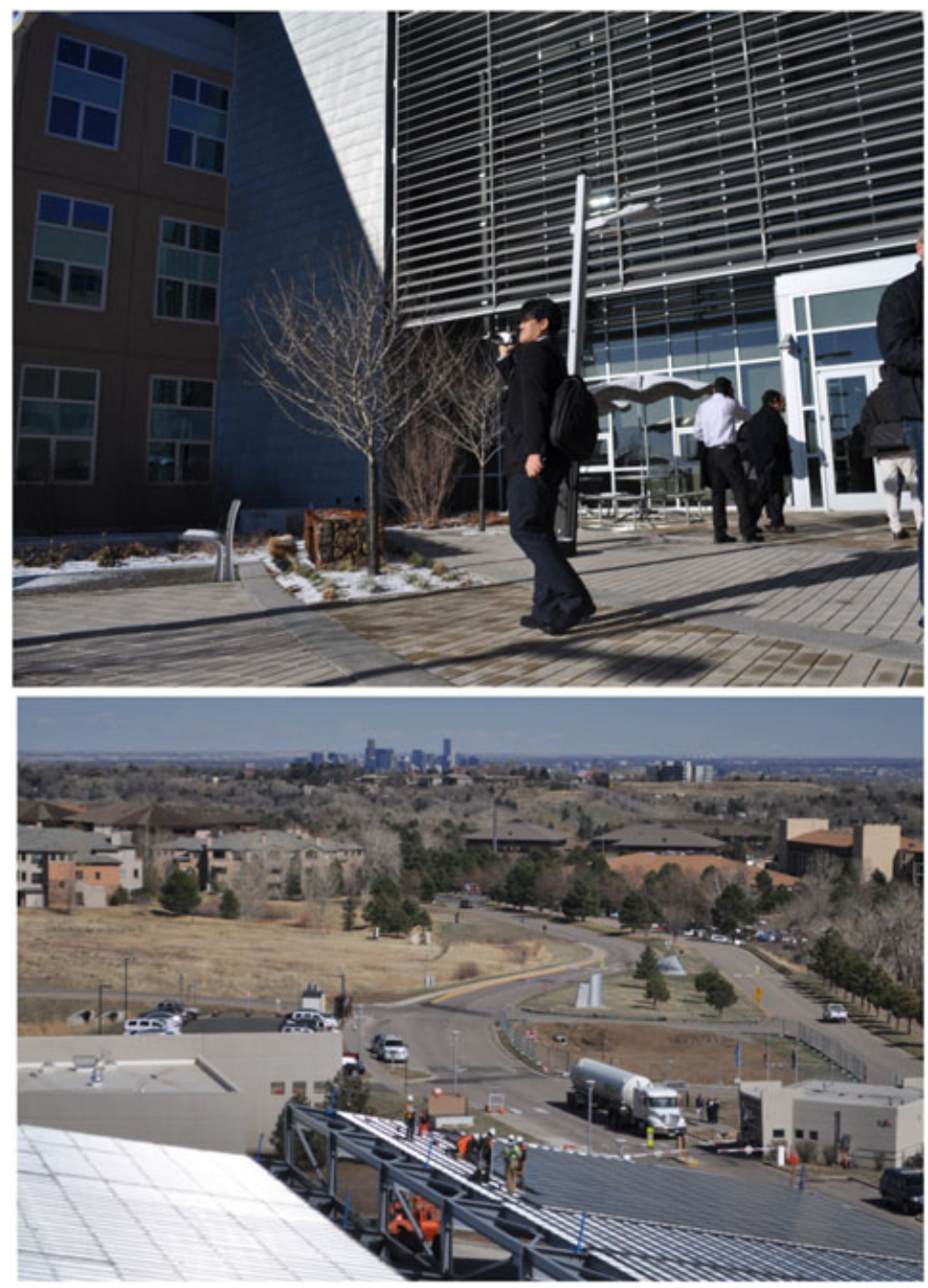

Figure 7. The NREL Research Support Facility, Golden, Colorado, US, 2011. Up: the building; down: the PV carport. The building is designed to be a prototype of ZEB. The PV carport on the parking area, despite detached from the building, and despite in any visual or functional relationship with the building, is considered within the building's boundary when calculating the energy balance. Design: Haselden and RNL's. Pictures @A. Scognamiglio. 
For example, a PV carport that is detached from a building, at the building's site, can be considered within the building's energy boundary for the calculation.

This way of setting the boundary does not take into account whether there is or not an architectural interaction of the carport with the building's system: that is, the shape of such a PV carport and its possible physical or visual relationship with the building.

Skipping planning legislation and property boundary considerations, from the design point of view, such 'PV additions' 'at-site' can be considered as a part of the building, only if designed together with the building itself, having a direct visual, formal or functional relationship with the building. This would imply that they are not actually 'additions' but rather, as parts of the site design together with the building itself.

As an example of such a design issue, we will give the NREL Research Support Facility (Figure 7), built in Golden, Colorado (USA) in 2011 and designed by the American firms Haselden [45] and RNL's [46]. The building has been designed to be a prototype of ZEB, and in fact, it obtains the ZE balance; but to get such a result, a PV carport has been placed at a certain distance from the building (at building's site), in the parking area, and the energy generation from this system has been accounted in the building's energy balance.

The carport does not relate in any way to the building's perception. It is physically 'at-site' but not designed together with the building, with the result that building and carport do not interact with each other, a part the energy balance.

We can summarize from these considerations that from the design point of view, the 'at-site' generation is part of the building's design only if it is in a formal relation with the building. A PV generator detached from a building has to be designed at the appropriate scale so to consider the building and the detached PV generator as parts of a whole system, that is, 'the site itself'.

\section{POSSIBLE FORMAL RESULTS FOR THE USE OF PV IN NET ZERO ENERGY BUILDINGS}

What are the possible formal results for the use of PV in ZEBs?

An analysis of the 30 case study buildings from 10 countries documented in the IEA SHC Task 40-ECBCS Annex 52-revealed that the buildings' solar PV systems were mostly delivering only a small fraction of the total energy need.

In spite of this, in many cases, the solar PV modules were sticking out the building's footprint, in a way that the design challenges had not been adequately addressed.

Nevertheless, conceiving a PV system in a Net ZEB so that its formal result is satisfying should be possible.

In the following, we will show some possible formal results for PV in ZEBs. We will start from the single building scale and with the energy generation within the building's envelope, to enlarge the discussion to the energy generation within the building's footprint, up to the 'on-site' generation, in the case of a single building or of a cluster of buildings.

The building can be seen as a fantastic integrator of technologies [47], which allows for the ZEB objective and for a good aesthetical performance, too.

As a very early and pioneering example where the building is conceived as an integrator of technologies, we will give the House Chanelle, designed by the Norwegian architect Harald Røstvik [48], built in Stavanger (Norway), on the occasion of the Future Exhibition in 1988 (Figure 8). Here, the main design principle is to apply the most relevant technologies necessary for the service, in a way where the systems supplement each other, creating synergies.

The Chanelle house shows that in the case of use of different integrated technologies, the use of PV has a limited formal, aesthetical influence on the building (Figure 9).

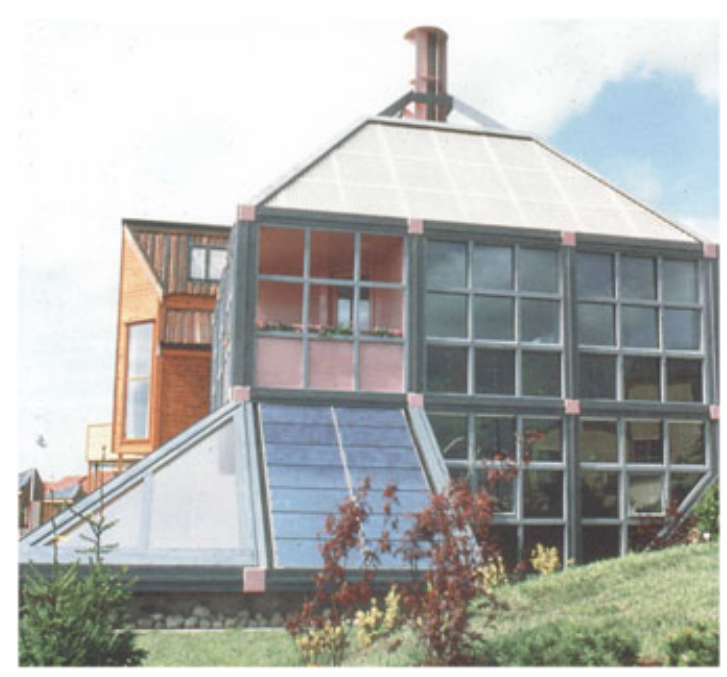

Figure 8. Chanelle House, Stavanger, Norway, 1988. PV is used together other solar technologies, and its influence on the building's image is quite limited. Design: H. N. Røstvik. Picture (C)H. N. Røstvik

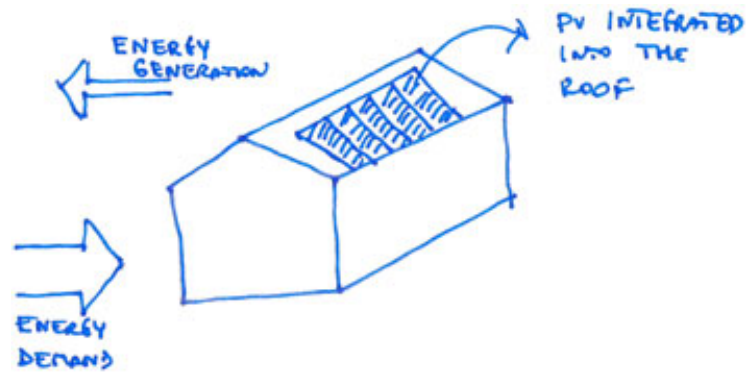

Figure 9. Conceptual sketch for a minimal formal result for the relationship between $\mathrm{PV}$ and the building, when using several energy technologies. (CA. Scognamiglio. 
But, as already said, PV has the potentialities to be the only energy carrier of a ZEB, and in this case, the aesthetics of the architectural design can be much more influenced by $\mathrm{PV}$.

More specifically, in this case, the PV area has to be calculated $\left(\mathrm{kW}_{\mathrm{p}}\right.$ or $\left.\mathrm{m}^{2}\right)$ so to generate the required energy (kWh/year) according to the ZEB balance. As a consequence, because generally the available area for PV is limited and constrained by the building features, the yield of the PV system has to be maximized. Both these parameters greatly influence the architectural design.

In fact, the yearly energy yield depends on both the placement, that is, the azimuth and tilt angles, of the modules and on the technical features of the PV modules. The optimal placement of the PV generator influences the shape of the building, and the technical features of the modules (e.g. colour, opaqueness and patterns of solar cells) limit the aesthetics of PV because they are chosen for maximum efficiency and minimum of costs.

To suggest a possible formal 'minimalistic' result of the relationship between energy self-sufficiency and the architectural design, when using the only PV as an energy carrier, we will give as an example a minimal self-sufficient spatial unit named CAPA, designed by the Portuguese architects Cannatà \& Fernandes [49], built in Matosinhos (Portugal) in 2003 (Figure 10).

CAPA is a parallelepiped with two glazed facades, based on a rectangle $30 \mathrm{~m}$ deep and $9 \mathrm{~m}$ long. The unit is equipped with a $2.2 \mathrm{~kW}_{\mathrm{p}}$ PV plane, made of standard modules, which is placed on the top of the unit and supplies electric energy for lighting systems, informatics, phones and security. In the case of such a simple building (a one-storey small unit having only a demonstrative function, with no boundary constraints), the formal result of the ZEB balance can be quite expected: a large sloped PV plane (blue surface) added on the building volume, made of standard opaque PV modules (maximum power density and efficiency, minimum cost).

This formal result can be defined as a minimal image of self-sufficiency, through PV, when optimizing the PV yield (Figure 11).

To investigate further the possible formal relationships between the ZEB paradigm and the aesthetics of architecture, in contrast with the simple condition of CAPA, we consider now a 'normal' building: for such a building-for example, one of the multi-storey buildings, we are used to live in or to work in-characterized by a number of functions and by a certain energy consumption, the formal result is generally not that expected.

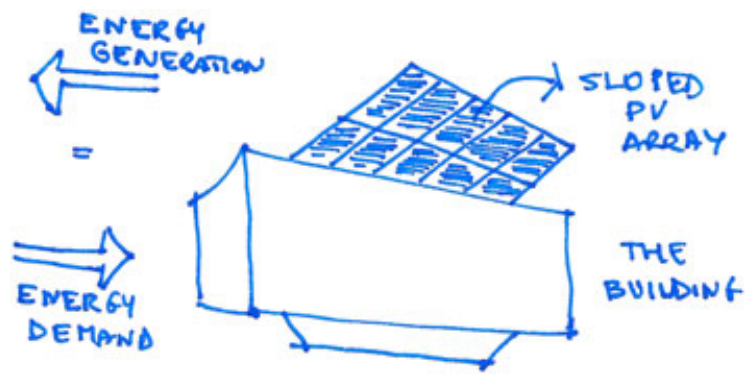

Figure 11. Conceptual sketch for a minimal formal result for the relationship between $\mathrm{PV}$ and the building in a one-storey building, when optimizing the PV yield. (A. Scognamiglio.

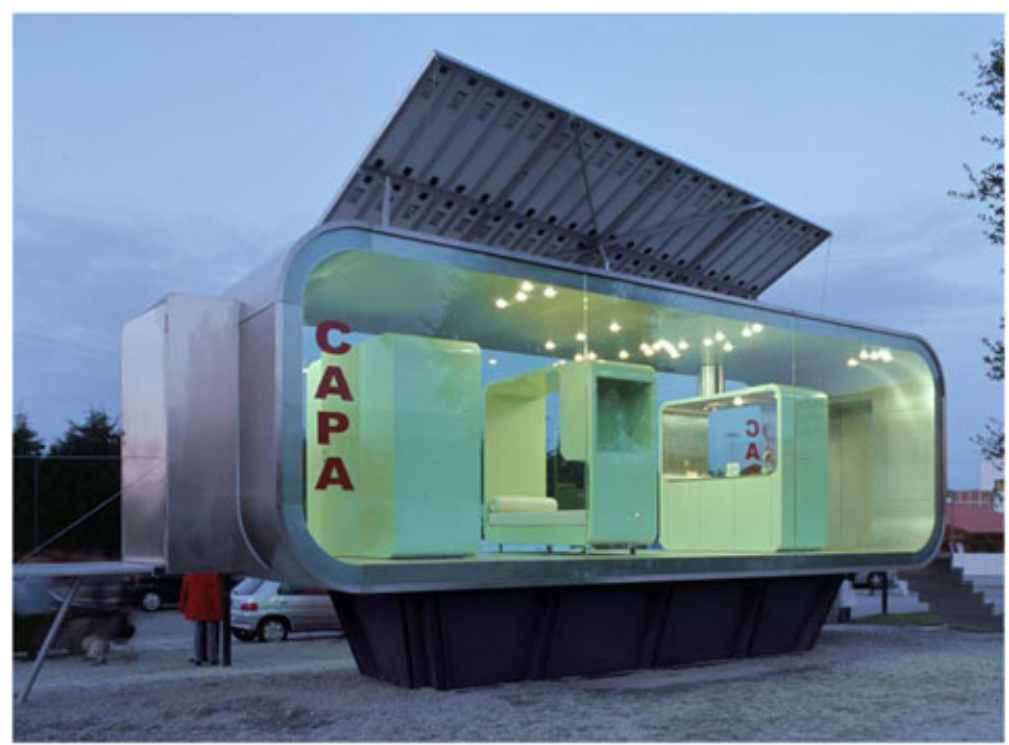

Figure 10. CAPA, Matosinhos, Portugal, 2003. The PV generator is shaped as a sloped plane that characterizes the image of the building. Design: Cannatà \& Fernandes. Picture @Cannatà \& Fernandes 
In this case, the only blue surface made of PV modules of CAPA, which looks like a 'hat' on top of the building, which is nevertheless included within the building's physical boundary, would be not enough. The building's physical boundary would be smaller than the PV area needed for powering the building energy consumption.

If we consider the average solar yield of PV in Norway, and in Italy, and compare with possible average yearly energy consumptions of buildings, we can have an idea on how large the PV generator should be for meeting the ZEB balance (Table I).

Formula : Required area $\left[\mathrm{m}^{2}\right]$ $=$ energy consumption $(\mathrm{kWh} / \mathrm{y}) /$ energy yield

$$
\left(\mathrm{kWh} / \mathrm{kW}_{\mathrm{p}} / \mathrm{y}\right) / \text { efficiency }\left(\mathrm{kW}_{\mathrm{p}} / \mathrm{m}^{2}\right)
$$

The calculation of the building's yearly energy demand should include all consumption sectors, especially electricity consumption [50].

As a consequence, roughly, every time a building has more than two stories in Italy and more than one in Norway, PV should look like a blue 'hat', sticking out the building physical boundary (Figure 12).

Because this kind of design outcome is not always appropriate (and feasible), it emerges the necessity to reduce as much as possible the building's energy demand, also through the improvement of the thermal performance of the PV modules. It emerges also that the ZEB target is feasible within the building's footprint, in reality, only for buildings having one or two floors.

The range of formal solutions for PV in the case of a standard multi-storey building is theoretically very wide, being the form of the special PV 'hat' a good exercise for design: several studies show that the architect has more freedom than expected (tilt and azimuth angles variations) without penalizing the energy generation that much [51], and the domain of the architects creativity is very wide. Nevertheless, the constraints related to the cities' morphology, especially in dense areas, limit the range of the formal solutions to a couple of them.

Table I. Surface requirements for PV modules to cover yearly energy consumption. Module efficiency: 12.5\%. Evaluation PV Gis, JRC.

\begin{tabular}{lcc}
\hline & Italy (Bari) & Norway (Oslo) \\
\hline PV Yield (kWh/kWp/year) & 1350 & 750 \\
Total yearly energy & \multicolumn{2}{c}{ PV area for } \\
consumption (kWh/m²/year) & each $10 \mathrm{~m}^{2}$ of floor space \\
\cline { 2 - 3 } 30 & \multicolumn{2}{c}{3.2} \\
60 & 3.6 & 6.4 \\
90 & 5.3 & 9.6 \\
100 & 60 & 107 \\
\hline
\end{tabular}

Note: Typical consumption for household electricity (illumination, appliances etc. is in the order of $30 \mathrm{kWh} / \mathrm{m}^{2} /$ year).

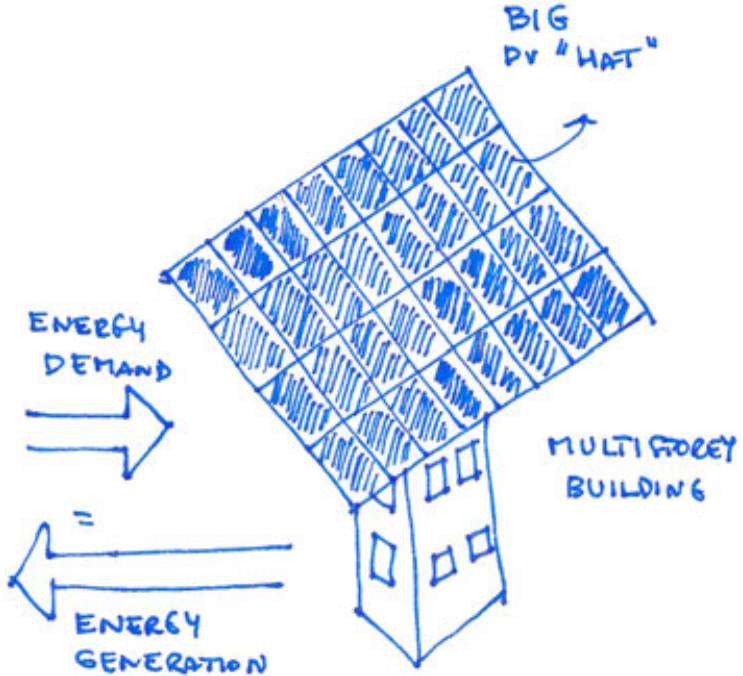

Figure 12. Conceptual sketch for a minimal formal result for the relationship between PV and a multi-storey building, PV looks like a big 'hat' sticking out the building. (CA. Scognamiglio.

We will give two examples of such solutions: the Rainbow Headquarters, designed by the Italian architects Bianchi \& Straffi and built in Loreto (Italy) in 2011 (Figure 13), and the SIEEB, designed by the Italian architect Mario Cucinella [52] and built in Beijing, China, in 2006 (Figure 14).

In the Rainbow headquarters, the PV modules, having a total nominal power of about $360 \mathrm{~kW}_{\mathrm{p}}$, can generate about $447 \mathrm{MWh} /$ year, which almost completely cover the energy needs for artificial lighting and power the HVAC system by using geothermal heat pumps.

Here, the conceptual PV 'hat' transforms into 'wings'. The PV modules are located on sheds (opaque on the South side and transparent for allowing the daylight on the North side), as well as on some canopies covering pedestrian walkways, and they are also placed on some support systems that create a sort of shed extension (wings) to the East.

Despite the SIEEB is not a ZE one, PV is again arranged in 'wings' on sun-shading devices but in a different way with respect to the Rainbow building. The 'wings' are arranged on strips sticking out the building's profile, which modify the parallelepiped form of the building into a kind of semitransparent half-pyramid.

The two examples we gave show that the formal repertoire for designing PV in Net ZEBs seems to be limited to a couple of solutions that benefit from the heritage of the outer-space architecture (Figure 15), by conceiving PV generators as 'wings' that stick out the building to catch the sunshine [53].

Obviously, if we think that buildings are generally parts of clusters, organized in a certain urban morphology, then there is a strict limit on if and how much these wings can stick out the building. Definitely, in dense cities, with multi-storey buildings, such a wing solution would be not appropriate. 


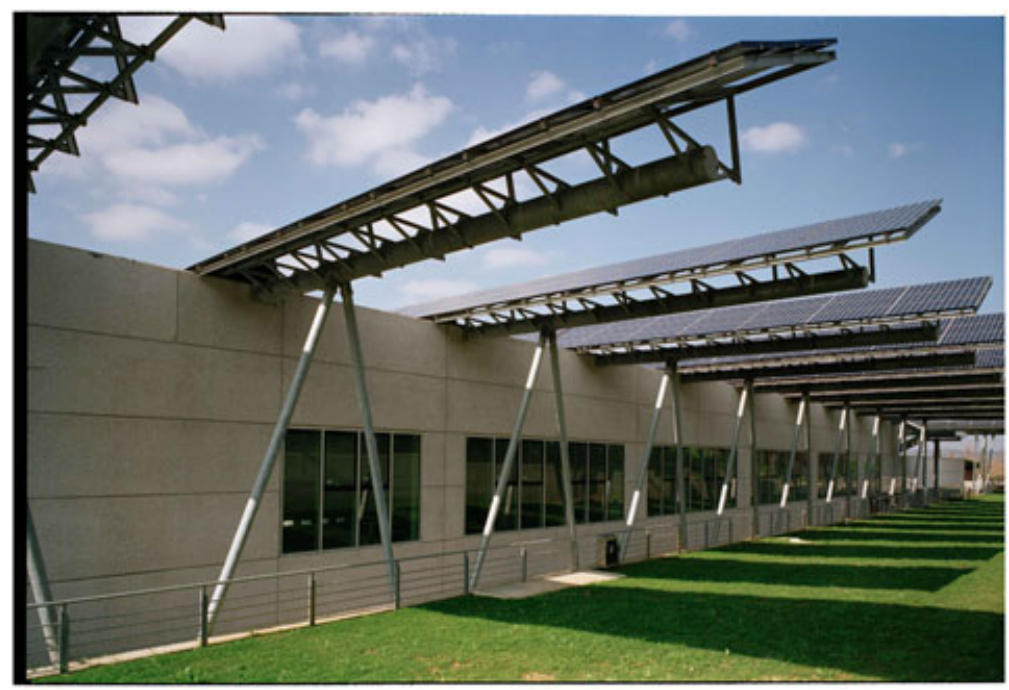

Figure 13. Rainbow Headquarters, Loreto, Italy, 2011, PV modules are arranged as wings hanging over from the building's boundary. Design: S. Bianchi \& E. Straffi. Picture by courtesy of the architects @L. Filateci.

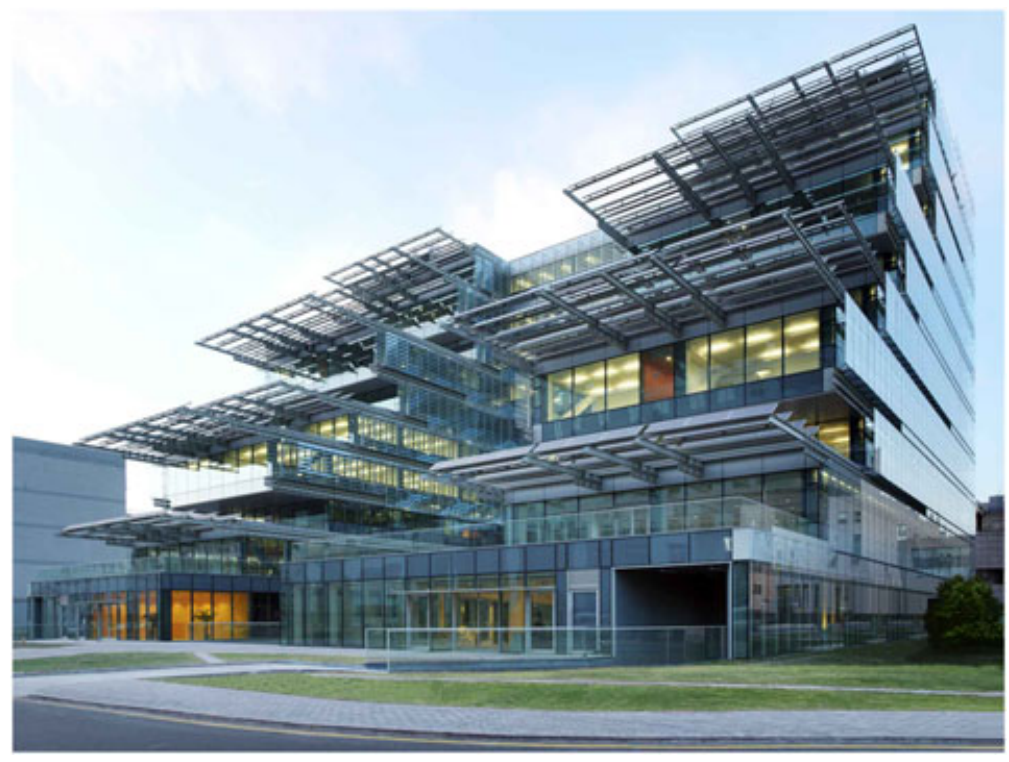

Figure 14. SIEEB building, Beijing, China, 2006. PV modules are arranged as wings that perform as sun-shading devices and give form to a kind of semitransparent half-pyramid. Design: MCA Mario Cucinella Architects. Picture @MCA Architects.

As examples of a possible formal solution for the use of PV in a ZE cluster of buildings, located in a dense city, we will give two projects: 'The Roof', designed in 2010 by the Italian architects Barreca \& La Varra [54], for an area in the city centre of Milan (Tortona), Italy, and the project for Plaza del General Vara del Rey in Madrid, Spain, designed by the Spanish architects ELII Oficina de Arquitectura (Uriel Fogu, Eva Gil Lopesino, Carlos Palacios) in 2009.

In the Italian project, the density of the built area, as well as the various shapes of the buildings, is serious obstacles to the use of PV; therefore, the design of PV results in a semitransparent roof, which protects a cluster of buildings, providing it with energy (Figure 16).

Here, the result of the use of PV is a hybrid space defined by the roof, used for both the habitat (buildings) and the energy generation (habitat metabolism).

Nevertheless, at the urban scale, one might also conceive an energy generation space, which is a hybrid space (people enjoinment and energy generation) but designed so to be separate from the buildings. 


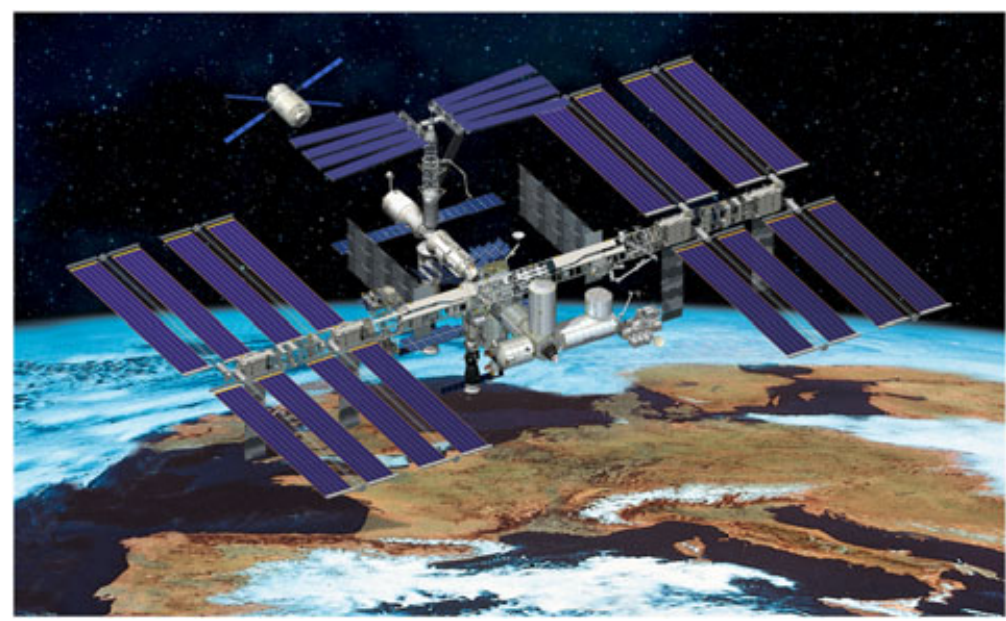

Figure 15. Outer-space architecture shows the attitude to extend large solar surfaces (wings) out the craft, to catch the solar radiation.

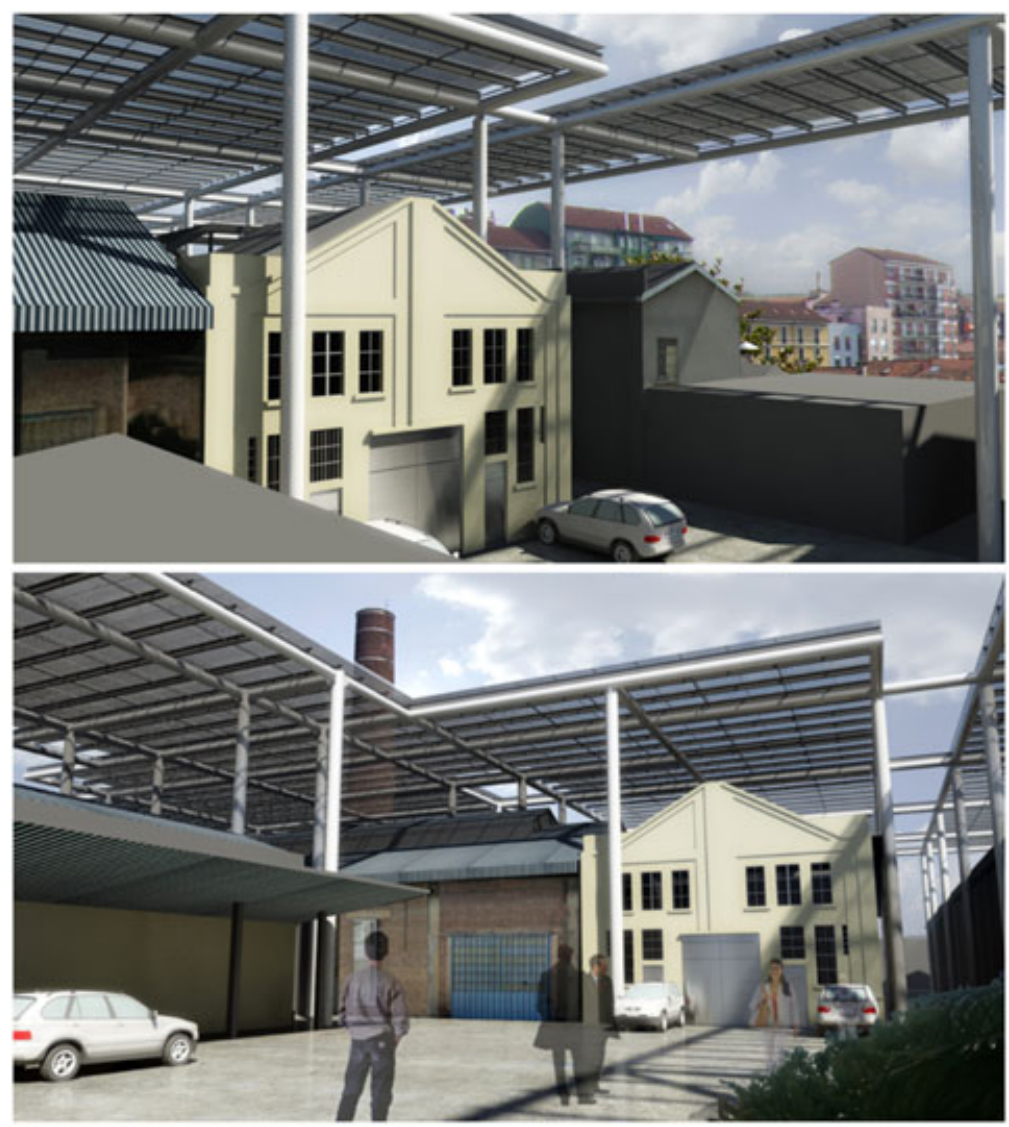

Figure 16. The Roof project, Milan, Italy, 2010. PV modules are arranged in a semitransparent roof that covers a cluster of buildings. Design: Barreca \& La Varra. Pictures by courtesy of the architects @Barreca \& La Varra.

In the Spanish project, a kind of PV pergola, made of a repetition of identical PV elements (resembling trees), becomes street furniture that can define space by providing shade or supporting a swing (Figure 17).
The project seeks to affirm not only environmental sustainability but also the social sustainability of an urban landscape that advantages from the presence of energy generation systems $[55,56]$. 


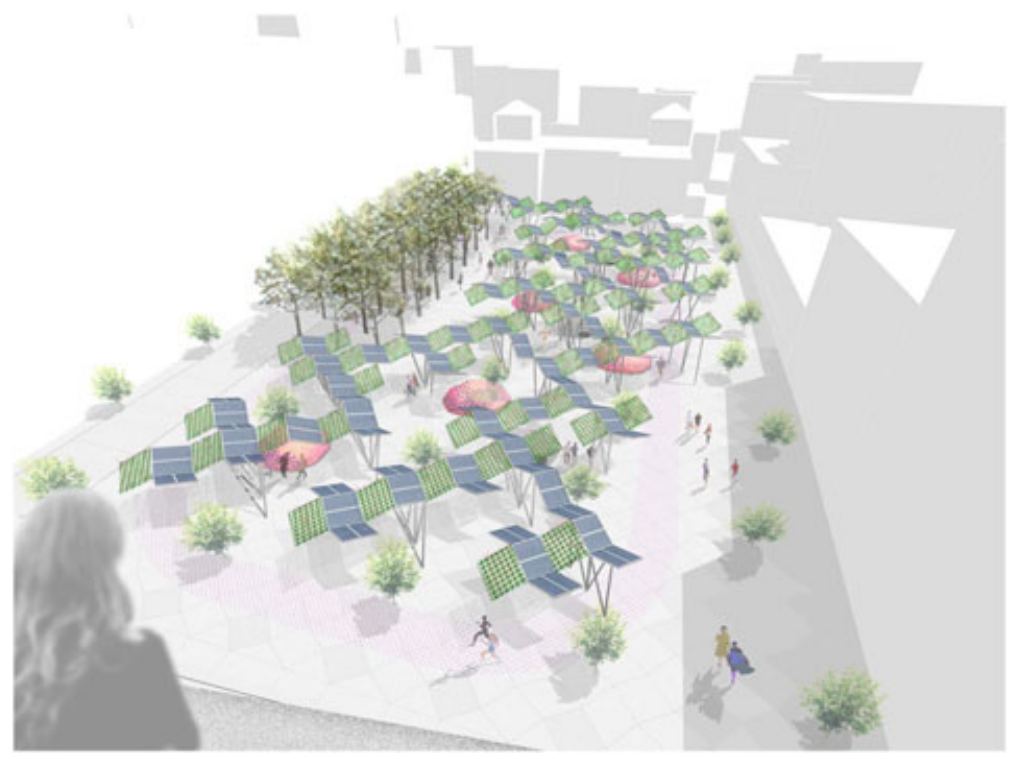

Figure 17. Plaza del General Vara del Rey project, Madrid (Spain), 2009. PV is shaped as a pergola made of technological trees that characterize the square. Design: ELII Oficina de Arquitectura. Picture by courtesy of the architects @ELII Oficina de Arquitectura.

\section{NET ZERO ENERGY BUILDING BALANCE: DESIGN SCALE IMPLICATIONS AND RESEARCH ISSUES FOR PV}

The Rainbow Headquarters and SIEEB examples demonstrate that for meeting the Net ZEB balance the only building's physical boundary is generally not sufficient. They result in the design of 'PV wings' that would generally unfeasible options for multi-storey buildings in dense cities.

The Roof and the Plaza general Vara del Rey projects show different formal possibilities for designing PV systems for clusters of buildings in dense cities, where the urban morphology limits the possibilities of enlarging the building's energy footprint to the building's surroundings ('at-site' energy generation). The formal results of both projects point toward the design of public hybrid spaces, where the people's enjoinment goes together with the energy generation. For both projects, the design scale is the urban one.

These considerations suggest that the result of the change in perspective from buildings with active surfaces not directly related to the building's energy balance, to Net ZEBs, is a kind of 'natural transition' from the architectural scale to the urban and landscape scale for the design of PV.

The design of 'at-site' solutions for PV seems to offer promising formal results for the use of PV if the PV generator, the building(s) and the public space are understood as part of only one system that can be defined ('urban') 'landscape'.

Note that according to the 'Landscape Ecology' [57], the landscape is understood as a living system, which includes a number of subsystems. The structure and the function of a landscape are characterized by boundaries (that separates the different systems from each other) and by a certain flux of energy. As a consequence, the landscape design takes into account in a systemic, ecological way, all the single part of the system as a whole [58].

As an example of 'at-site landscape PV design' we will give the Solar Strand, designed by the Californian landscape architect Walter Hood [59], built in 2012 at the Buffalo University (USA).

In 2010, the University of Buffalo launched a competition for the design of a 1.1 MW $\mathrm{p}$ PV (5500 PV modules) system to be placed in the campus area for powering the dormitories. The design challenge was transforming a large PV system from a mere technical system into an element of the campus landscape, which could make people more confident with the place they live in.

Hood conceived an array of PV modules, whose pattern was designed as if the modules were the elements of a DNA molecule (Figure 18).

This DNA pattern array defines a new form for the external campus area. For example, the patterns of the rows of modules, and the different heights of these rows, help people to orientate themselves in the campus. Native plants have been used for vegetating the soil under the modules, so that this area offers people a pleasant place for a rest or a walk.

Despite the large dimension of this project, a special attention has been paid also to the small scale, in designing innovative supporting structures, made of carefully designed (appealing) elements containing the electric cables (for people safety).

The Buffalo Solar Strand demonstrates that in the case of buildings characterized by high energy demands, the balance boundary can extend to the building's site, at a large scale, that can be defined a landscape scale.

The design of such an 'at-site' PV energy generation systems offers the architect a great opportunity. The 


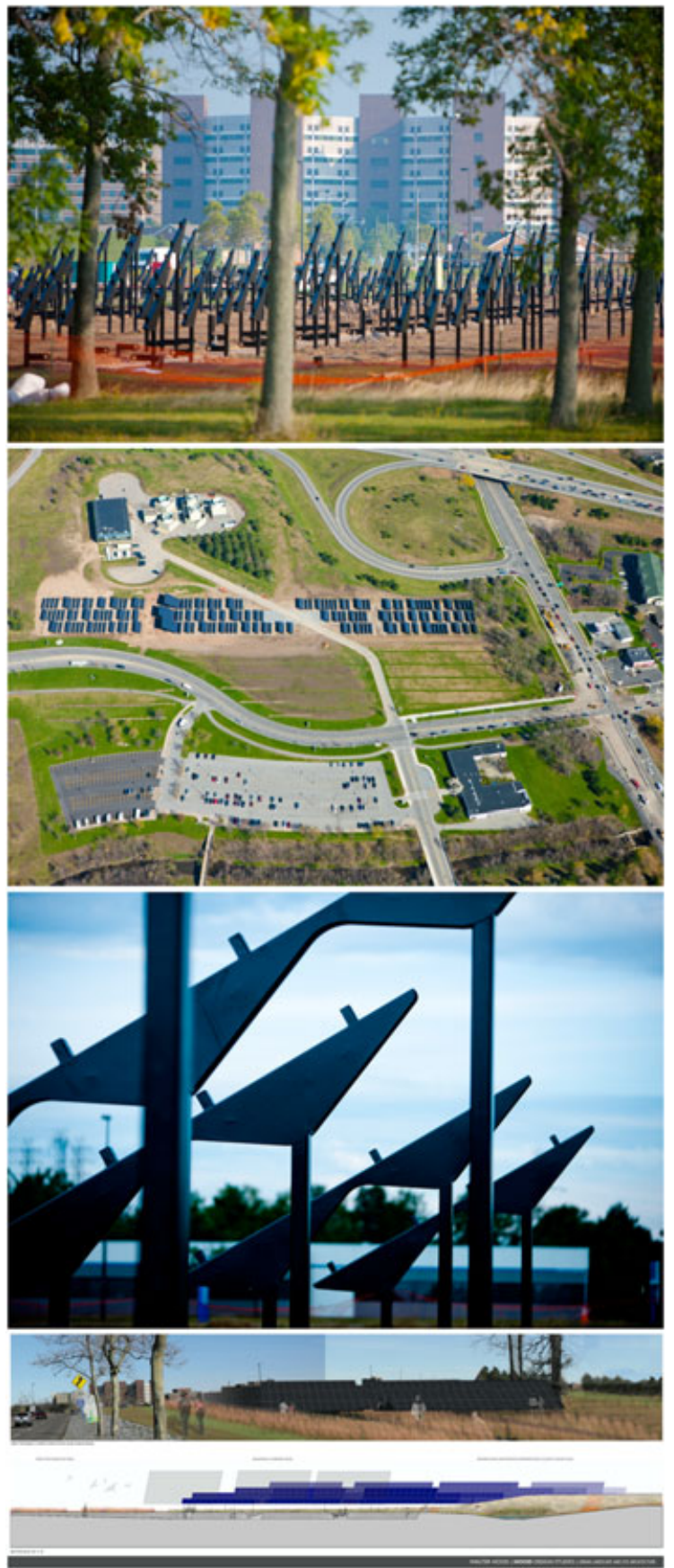

Figure 18. The Solar Strand, Buffalo University Campus, Buffalo (US), 2011. The PV modules on the ground are arranged according to a DNA pattern. They give form to a public space in a direct functional and visual relationship with the buildings of the campus. Design: Walter Hood, Hood Design. Pictures by courtesy of the architect @W. Hood.

realization of a large on ground PV system can be transformed into a landscape design composition with outstanding results in terms of landscape design.
To achieve a good PV design at the landscape scale a design approach able to cross over different scales of design is needed (Landscape Ecology).

The Buffalo Solar Strand suggests also a question for our research: what is the scale of investigation for the use of PV in Net ZEBs?

To answer this question is not that easy; nevertheless, new research taking into account the possibility of thinking PV as a 'Landscape-integrated PV (LIPV)' is certainly a new fertile domain of investigation.

\section{NUTSHELL CONCLUSIONS}

From a design point of view, the main challenge in a near future will be approaching the issue of the use of PV in Net ZEBs from a systemic perspective. This means to look at the building not as to a single building but as a part of a larger system of buildings (cluster), being also this system of buildings part of an even larger system (i.e. the city or the landscape).

We know from Biology that it is not possible to investigate a living unit without taking into account the environment whit that this unit interacts [60]. In a similar way, it seems that it is not possible to achieve the Net ZE balance of a building without taking into account the complex systems the building is part of and the other single units the building interacts with.

For instance, a true NZEB could also account for the carbon balance of the original site. Questions such as has vegetation that ties carbon been removed and will the building create shade to other buildings thus cool them and increase their heat and daylight need are issues that should be addressed in future research.

As a first result of this work, we believe that at least, the existing categorizations for the use of PV in buildings have to be rethought taking into account the ZEB definitions and the enlargement of perspective required for considering the 'on-site' and 'nearby' energy generation mentioned in the EU EPBD.

We think that, to describe the way PV is used in a ZEB, some information on the building boundary conditions taking into account the energy balance should be given to compare different ways of using PV in Net ZEBs, for example: the building typology (office, educational, housing, etc.); the climate (cooling dominated, heating dominated, heating and cooling dominated); the number of occupants (people $/ \mathrm{m}^{2}$ ).

The PV system should be described in terms of energy generated versus power installed $\left(\mathrm{kWh} / \mathrm{m}^{2} /\right.$ year vs $\left.\mathrm{kW}_{\mathrm{p}} / \mathrm{m}^{2}\right)$, in relation to the energy balance boundaries (which consumptions are accounted) and percentage of the building's energy balance powered by PV.

We showed some possible formal results both for the use of PV on building's footprint and on building's site.

The building's footprint energy generation does not require new categories for describing PV. The only addition would be the typology of the 'wings': PV elements sticking 
out the building. In terms of generation 'at-site', then the detached PV systems should be described for the form they take in relation to the building and to the landscape they belong to.

We showed that when dealing with dense city, it is necessary to think in terms of cluster of buildings for achieving a ZE balance. The formal result of the use of PV for clusters of buildings can be the design of hybrid public spaces where the people's enjoinment is mixed with the energy generation.

We also showed that the 'at-site' energy generation should be approached from the Landscape Ecology perspective. The formal results of the use of PV 'at-site' can be appreciable at the landscape scale.

This demonstrates the possibility to think of 'Landscape Integrated Photovoltaics (LIPV)' as the next domain for the PV investigation from the design point of view (site-integrated PV).

It is worth to note that this enlargement of perspective from the architectural scale (building) to the urban (cluster of buildings) and landscape scale meets the principles of the Landscape Urbanism [61], as well as the ones of the Ecological Urbanism [62], enabling to make a bridge over the energy research and the design research.

Note that obviously, the examples we gave do not show all the formal possibilities for using PV in Net ZEBs. Much research is still to be done, but current experimentations on large scale building design (i.e. landform architecture) show that designing buildings as part of the landscapes opens new frontiers. By looking at the building as an artificial landscape, the traditional forms for buildings and cities would completely changed. Traces of this research can be found in the early pioneering work of the Italian architect Paolo Soleri on self-sufficient cities [63]. The Danish architect Bjarke Ingels (BIG Copenhagen, former PLOT) [64] developed in 2004 a whole planning for an energy self-sufficient Denmark (Danish official contribution to the IX Architecture Exhibition of the Biennale of Venice) [65]. A group of researchers and architects has been already investigating concepts of LIPV [66].

In regard of the new product development for PV, as first results of the investigation, we can say that the focus should be on structural and thermal new functional features of PV modules and related standards to meet the ZEBs balance by improving the envelope energy efficiency, when PV is used into the building's envelope. Nevertheless, in the case of the use of PV 'at-site', also the design of aesthetically pleasing, safe and easy mounting system is important, so that the ground where PV is located can have a double function for the people's enjoinment, as well as for the landscape equipment.

\section{ACKNOWLEDGEMENTS}

The work presented in this paper has been developed by the authors in the context of the join IEA SHC Task 40-ECBCS Annex 52 named 'Towards Net Zero Energy
Solar Buildings'. The authors, participating in the working group, would like to thank all the participants and in particular the operating agent Josef Ayoub. The architectural investigations have been mainly developed in the context of ENEA-Domus collaboration, which has the form of a periodic column named 'Forms of Energy' and published on www.domusweb.it. The investigation on the landscape was mainly developed on the occasion of the $\mathrm{PhD}$ thesis: Scognamiglio A., 'Serre agricole, energia e paesaggi', Second University of Naples (IT), Faculty of Architecture Luigi Vanvitelli, 2010. It was also inspired by the presentations of international architects at the 'Photovoltaics, Forms, Landscapes' event, held in 2011 in Hamburg within the 26th EUPVSEC.

Architectural investigations of free standing solar systems were partly developed by Røstvik H.N. as a response to the "don't touch" the listed buildings challenge raised in the BRITA in PuBs-Bringing Retrofit Innovation to Application in Public Buildings under the EU 6th Framework Programme. Project website www.brita-in-pubs.eu.

\section{REFERENCES}

1. EPBD recast. Directive 2010/31/EU of the European Parliament and of the Council of 19 May 2010 on the energy performance of buildings (recast). Official Journal of the European Union, 2010 http://www.energy.eu/directives/ 2010-31-EU.pdf (accessed 26/08/2012).

2. IEA SHC Task 40-ECBCS Annex 52, Towards Net Zero Energy Solar Buildings. http://www.iea-shc.org/ task40/, 2008 (accessed 22/05/2012).

3. Voss K, Musall E. Net Zero Energy Buildings. International Projects on Carbon Neutrality in Buildings. Birkhäuser Architecture: Munich (DE), 2012.

4. Argan GC. Storia Dell'arte Come Storia Della Città. Editori Riuniti: Roma (IT), 1993.

5. Rossi A. L'architettura Della Città, Marsilio, Padova 1966; new edition Quodlibet, Macerata (IT), 2011.

6. Venturi R, Scott Brown D, Izenour S. Learning from Las Vegas: the Forgotten Symbolism of Architectural Form. MIT Press: Cambridge (US), 1977.

7. Koolhas R, Mau B. S, M, L, XL. Monacelli Press: New York (US), 1997.

8. Scognamiglio A, Ossenbrink H, Annunziato M. Forms of cities for energy self-sufficiency. Proceedings UIA 2011 Tokyo, The XXIV World Congress of Architecture, 2011; 22-27.

9. Voss K, Kiefer K, Reise C, Meyer T. Building energy concepts with photovoltaics - concept and examples from Germany. Advances in solar energy, American Solar Energy Society, Boulder, USA 2003; 15: 235-259.

10. Scognamiglio A, Bosisio P, Di Dio V. Fotovoltaico Negli Edifici. Edizioni Ambiente: Milano (IT), 2009; 201-264. 
11. Farkas K, Frontini F, Maturi L, Roecker C, Scognamiglio A. Architectural integration of solar systems: criteria \& guidelines (photovoltaics). in press on www.iea-shc. org/task41, 2008 (accessed 22/05/2012).

12. Scognamiglio A. Fotovoltaico e architettura produttiva. In Architettura Produttiva. Principi di Progettazione ecologica, Palumbo ML (ed). Maggioli Editore (IT), 2012; 87-105.

13. Scognamiglio A. In Fotovoltaico e architettura produttiva. Palumbo ML (ed). Architettura Produttiva. PRINCIPI di Progettazione Ecologica: Maggioli Editore (IT), 2012; 87-105.

14. Van S. The aesthetics of sustainability. In Architecture of Change, Sustainability and Humanity in the Built Environment, Feiress K, Feiress L (ed). Die Gestalten Verlag: Berlin (DE), 2003; 130-135.

15. Geli RE (Cloud 9), Vallejo JL (Ecosistema Urbano), Jongert J (2012 Architekten), Boeri S (Boeri Studio). A declaration to address the global energy crisis and climate change. XI International Architecture Exhibition of the Biennale of Venice, 2008, in http://www. greenville.it/media/Files/13_dichiarazione_venezia.pdf (accessed 26/05/2012).

16. Scognamiglio A, Bordone S, Grima J, Palumbo ML. "Forms of Energy": the way architects envision the use of solar energy. Proceedings of the 26th EUPVSEC, 2011; 3958-3966.

17. Calculations done for $0,1 \mathrm{~kW}_{\mathrm{p}}$ for Oslo and Bari, respectively, by using the tool PVGIS. Available at: http://re. jrc.ec.europa.eu/pvgis/apps4/pvest.php\# (accessed 25/ 05/2012).

18. Humm O, Toggweiler P. Photovoltaik und ArchitekturDie Integration von Solarzellen in Gebäudehüllen. Birkhäuser: Basel (CH), 1993.

19. Schoen TJN, Schmidt H. Building-integrated PV activities within the IEA framework: going from Task 16 to Task 7. Progress in Photovoltaics: Research and Applications 1996; 6: 237-245.

20. Hagemann IB, Gebäudeintegrierte Photovoltaik, Architektonische Integration der Photovoltaik in die Gebäudehülle. Rudolf Müller: Köln (DE), 2002.

21. Abbate C. L'integrazione Architettonica del Fotovoltaico. Casi Studio Internazionali Della Tecnologia Solare. Gangemi Editore: Roma (IT), 2006.

22. Gaiddon B, Kaan H, Munro D. Photovoltaics in the Urban Environment. Lessons Learnt from Large-scale Projects. Earthscan: London (UK), 2009.

23. Scognamiglio A, Privato C. Starting points for a new cultural vision of BIPV. Proceedings of the 23rd European Photovoltaic Solar Energy Conference, 2008; 3222-3233.

24. Reijenga T, Teeuw P. Building integrated photovoltaic in architecture. Proceedings of the 21st EUPVSEC, 2006; 2838-2843.
25. Changhai P, Ying H., Zhishen W. Buidling-integrated photovoltaics (BIPV) in architectural design in China. Energy and Buildings 2012; 43: 3592-3598.

26. Guida alle applicazioni innovative finalizzate all'integrazione architettonica del fotovoltaico, revisione 1-Agosto 2011. GSE, 2011; http://www.gse.it/it/Conto\%20Energia/ GSE_Documenti/Fotovoltaico/Evoluzione $\% 20 \mathrm{del} \%$ 20Conto\%20Energia/05\%20Guide/Guida\%20alle $\%$ 20applicazioni\%20innovative\%20finalizzate\%20all' integrazione $\% 20$ architettonica $\% 20 \mathrm{del} \% 20$ fotovoltaico \%20\%20Rev1.pdf (accessed 26/05/2012).

27. Jelle BP, Breivik C, Røkenes HD. Building integrated photovoltaic products: A state-of-the-art review and future research opportunities. Solar Energy Materials \& Solar Cells 2012; 100: 69-96. DOI: 10.1016/j. solmat.2011.12.016

28. Hagemann IB. Perspectives and challenge of BIPV product design. Proceedings of the 26th EUPVSEC, 2011; 4016-4022.

29. http://www.iea-shc.org/task16/ (accessed 25/05/2012)

30. www.task7.org (accessed 22/05/2012).

31. www.iea-pvps-task10.org (accessed 22/05/2012).

32. www.iea-shc.org/task41 (accessed 22/05/2012).

33. Reijenga T, Kaan H. Photovoltaics in an architectural context. Progress in Photovoltaics: Research and Applications 2004; 12: 359-408. DOI: 10.1002/pip.554

34. www.marcoacerbis.com (accessed 27/05/2012).

35. http://www.domusweb.it/en/architecture/forms-of-energy7-/ (accessed 27/05/2012).

36. www.exitstudio.it (accessed 27/05/2012).

37. http://www.domusweb.it/en/architecture/forms-of-energy9/ (accessed 27/05/2012).

38. Feiress L. Building up responsibility in critical times. In Architecture of Change 2, Feiress L, Feiress K (eds). Die Gestalten Verlag: Berlin (DE), 2008, 16.

39. www.snoarc.no (accessed 22/05/2012).

40. http://www.ecobuildings.info/eco-culture/oslo.html http:// www.cowiprojects.com/ecoculture/Opera_House_Results. html (accessed 28/05/2012)

41. Sartori I, Napolitano A, Voss K. Net zero energy buildings: a consistent definition framework. Energy and Buildings 2012. DOI: 10.1016/j.enbuild.2012.01. 032 (in press)

42. Torcellini P, Pless S, Deru M, Crawley D. Zero Energy Buildings: a critical look at the definition. Conference Paper NREL/CP-550-39822, US, 2006, available on http://www.nrel.gov/docs/fy06osti/39833.pdf (accessed 28/05/2012).

43. Marszal AJ, Heiselberg P. A Literature Review on ZEB Definitions. Aalborg University: DK, 2009.

44. http://wiki.answers.com/Q/What_is_the_definition_of_a_ building_footprint (accessed 27/05/2012).

45. http://haselden.com/ (accessed 28/05/2012). 
46. http://www.rnldesign.com/ (accessed 28/05/2012).

47. Mercaldo LV, Addonizio ML, Della NM, Delli Veneri P, Scognamiglio A, Privato C. Thin film silicon Photovoltaics: architectural perspectives and technological issues. Applied Energy 2009; 86: 1836-1844. DOI: 10.1016/j.apenergy.2008.11.034

48. http://www.sunlab.no/ (accessed 28/05/2012).

49. http://www.cannatafernandes.com/ (accessed 28/05/2012.

50. Voss K, Musall E, Lichtmeß M. From low-energy to Net Zero-Energy Buildings: status and perspectives. Journal of Green Building 2011; 6(1): 53.

51. Røstvik HN. The Sunshine Revolution. Sun-Lab Publishers: Stavanger (NO), 1992; 36-37.

52. http://www.mcarchitects.it (accessed 27/05/2012).

53. http://www.domusweb.it/en/architecture/forms-of-energy14-/ (accessed 24/05/2012).

54. www.barrecaelavarra.it (accessed 27/05/2012).

55. Foguè U, Palacios C, Gil E. elii [architecture ofice], integrating photovoltaic solar power: activation of the public spaces of city entres (case study: pilot project for the General Vara del Rey square in Madrid, Spain). Proceedings of the 25th EUPVSEC-5th WCPEC, 2010, 4893-4898.
56. http://www.domusweb.it/en/architecture/forms-ofenergy-1/ (accessed 27/05/2012).

57. http://en.wikipedia.org/wiki/Landscape_ecology (accessed 28/05/2012).

58. Forman RTT. Land Mosaics. The Ecology of Landscape and Regions. Cambridge University Press: Cambridge (UK), 1995.

59. www.wjhooddesign.com (accessed 28/05/2012)

60. Maturana HR, Varela KJ. Autopoiesi e Cognizione. Marsilio: Venezia (IT), 2004; 54.

61. Waldheim C (ed). The Landscape Urbanism Reader. Princeton Architectural Press: New York (US), 2006.

62. Mostafavi M, Doherty G (eds). Ecological Urbanism, Harvard Graduate School of Design, Lars Müller Publishers: Baden (CH), 2010.

63. Soleri P. Arcology. The City in the Image of Man. MIT press: Cambridge (US), 1969, new edition Cosanti Press, Scottsdale, Arizona (US), 2006.

64. http://www.big.dk (accessed 29/05/2012).

65. http://www.dac.dk/db/filarkiv/8375/HySociety.pdf (accessed 29/05/2012).

66. http://www.pv-landscapes.com/cms/ (accessed 29/05/ 2012). 